\begin{tabular}{|l|l|l|}
\hline \multicolumn{2}{|c|}{ PublisherInfo } \\
\hline \hline PublisherName & $:$ & BioMed Central \\
\hline \hline PublisherLocation & $:$ & London \\
\hline \hline PublisherImprintName & $:$ & BioMed Central \\
\hline \hline
\end{tabular}

\title{
Serine protease Jurassic Park
}

\begin{tabular}{|l|l|l||}
\hline \multicolumn{2}{|c|}{ ArticleInfo } \\
\hline \hline ArticleID & $:$ & 4837 \\
\hline \hline ArticleDOI & $:$ & $10.1186 /$ gb-spotlight-20030903-01 \\
\hline \hline ArticleCitationID & $:$ & spotlight-20030903-01 \\
\hline \hline ArticleSequenceNumber & $:$ & 189 \\
\hline \hline ArticleCategory & $:$ & Research news \\
\hline ArticleFirstPage & $:$ & 1 \\
\hline \hline ArticleLastPage & $:$ & 2 \\
\hline \hline & & RegistrationDate : 2003-9-3 \\
\hline ArticleHistory & $:$ & OnlineDate \\
\hline \hline ArticleCopyright & $:$ & BioMed Central Ltd2003-9-3 \\
\hline \hline ArticleGrants & $:$ & \\
\hline \hline ArticleContext & $:$ & 130594411 \\
\hline \hline
\end{tabular}




\section{Cathy Holding}

Email: cholding@hgmp.mrc.ac.uk

Serine proteases function in cascade systems such as blood clotting, immunity, and digestive processes. Family and evolutionary relationships among the various enzymes can be inferred from highly conserved markers that can be extended to the enzyme substrates as well, and members are classified from their primary specificities. Several members of the trypsin superfamily have non-trypsin-like primary specificities, but attempts to determine their phylogeny have so far failed. In the August Molecular Cell, Merridee Wouters and colleagues at the Victor Chang Cardiac Research Institute report the construction and functional analysis of a synthetic protein predicted theoretically to be the ancestor of the present-day enzymes trypsin, chymotrypsin, and elastase, and discover that it has a wider tolerance for substrates than both its descendents and its own ancestor (Molecular Cell 2003, 12:343-54).

Wouters et al. inferred ancestral sequences from parsimony analysis of a multiple alignment of 56 immune defense protease (IDP) sequences and constructed a synthetic gene to express the recombinant protein that they called Stemzyme-IDP- $\beta$. Using angiotensin II as substrate for kinetic and binding studies, the authors observed high catalytic efficiency and broad substrate specificity and a tolerance to mutation at the binding site, with different mutations resulting in activities similar to some of the synthetic enzyme's descendents. They suggest that a form of reverse evolution must have occurred that provided a mechanism for enzymes with narrow specificity to evolve from enzymes with already narrow specificity.

"Our findings... suggest that once a narrow primary specificity had become established, the further generation of diversity required a reversion to the presumed original state. That is, despecialization or evolution-in-reverse was required for further diversification," the authors conclude.

\section{References}

1. Evolution of enzyme cascades from embryonic development to blood coagulation

2. Molecular Cell, [http://www.molecule.org/]

3. Victor Chang Cardiac Research Institute, [http://www.victorchang.com.au/index.asp]

This PDF file was created after publication. 